\title{
Azospirillum brasilense INOCULATION ON SEED GERMINATION AND INITIAL GROWTH OF SEEDLINGS OF NATIVE FOREST SPECIES
}

\author{
Francival Cardoso Felix ${ }^{1 *}$, Daniele Cristina Pereira de Matos², Leandro Porto Latoh ${ }^{3}$, Renata de Almeida \\ Maggioni $^{4}$, Antônio Carlos Nogueira ${ }^{5}$ \\ 1*Universidade Federal do Paraná, Programa de Pós-Graduação em Engenharia Florestal, Curitiba, Paraná, Brasil - \\ franciva1007@gmail.com \\ ¿2Universidade Federal do Paraná, Programa de Pós-Graduação em Engenharia Florestal, Curitiba, Paraná, Brasil - \\ danielecpm92@gmail.com \\ ${ }_{3}^{3}$ Universidade Federal do Paraná, Programa de Pós-Graduação em Engenharia Florestal, Curitiba, Paraná, Brasil - leandrolatoh@ gmail.com \\ ${ }^{4}$ Universidade Federal do Paraná, Programa de Pós-Graduação em Engenharia Florestal, Curitiba, Paraná, Brasil - \\ remaggioni89@gmail.com \\ ${ }_{5}^{5}$ Universidade Federal do Paraná, Programa de Pós-Graduação em Engenharia Florestal, Curitiba, Paraná, Brasil - \\ acnogueira.ufpr@gmail.com
}

Received for publication: 05/05/2020 - Accepted for publication: 13/10/2020

\begin{abstract}
Resumo
Inoculação de Azospirillum brasilense na germinação de sementes e crescimento inicial de mudas de espécies florestais nativas. A inoculação de rizobactérias em sementes e plantas tem sido documentado como estimulante e promotor da germinação e crescimento de culturas agrícolas, entretanto, há poucas informações com espécies florestais nativas. Diante disto, o presente trabalho tem por objetivos avaliar o potencial da inoculação de Azospirillum brasilense na germinação de sementes e crescimento inicial de mudas de espécies florestais nativas. Foram realizados os experimentos de: (I) germinação de sementes em câmara de germinação, e (II) crescimento inicial de mudas em viveiro, ambos com quatro espécies florestais (Cassia leptophylla, Lafoensia pacari, Mimosa flocculosa e Schinus terebinthifolius). Para as quatro espécies, em ambos os experimentos, utilizou-se dois tratamentos: inoculação das sementes com solução concentrada de $A$. brasilense, e sem inoculação das sementes (controle). Foram avaliados aspectos fisiológicos de germinação de sementes e vigor de plântulas no primeiro experimento (velocidade de germinação, comprimento e massa seca de plântulas), e de crescimento de mudas no segundo experimento (altura, diâmetro do colo e massa seca de mudas). A inoculação de A. brasilense em sementes de C. leptophylla, L. pacari, M. flocculosa e $S$. terebinthifolius não apresentou resultados benéficos ou promissores para a germinação de sementes e crescimento inicial de mudas, logo não se recomenda o seu uso para a produção de mudas dessas espécies.

Palavras-chave: rizobactéria, produção de mudas, raízes secundárias, fisiologia de semente
\end{abstract}

\section{Abstract}

Inoculation of rhizobacteria in seeds and plants has been documented as a stimulant and promoter of germination and growth of agricultural crops, but there is little information on native forest species. Therefore, the present study aims to evaluate the potential of Azospirillum brasilense inoculation in the germination of seeds and initial growth of seedlings of native forest species. The following experiments were carried out: (I) germination of seeds in germination chamber, and (II) initial growth of seedlings in nursery, both with four forest species (Cassia leptophylla, Lafoensia pacari, Mimosa flocculosa and Schinus terebinthifolius). For the four species, in both experiments, two treatments were used: inoculation of seeds with concentrated solution of $A$. brasilense and no inoculation of seeds (control). Physiological aspects of seed germination and seedling vigor were evaluated in the first experiment (germination speed, and length and dry weight of seedlings), and seedling growth was evaluated in the second experiment (height, collar diameter and dry weight of seedlings). Inoculation of A. brasilense in seeds of C. leptophylla, L. pacari, M. flocculosa and S. terebinthifolius did not promote beneficial or promising results for seed germination and initial growth of seedlings, so its use to produce seedlings of these species is not recommended.

Keywords: rhizobacteria, seedling production, secondary roots, seed physiology.

\section{INTRODUCTION}

The growing awareness of society about the benefits of forest and landscape restoration has stimulated an engagement among many countries to develop global restoration commitments linked to national policies, aiming to turn large-scale forest restoration into reality (SUDING et al., 2015; CHAZDON et al., 2016). In Brazil, global agreements aligned with national policies have led to an increase in the demand for seedlings of native forest species, in order to minimize the damage caused to the environment, resuming ecosystem services and conserving biodiversity (MESQUITA et al., 2010; RODRIGUES et al., 2011; SILVA et al., 2016).

The success in the production of forest seedlings for economic or conservation purposes depends on the knowledge of the aspects of seed germination and seedling formation. The germination process in the seed can be affected by external or environmental factors, such as temperature, oxygen, moisture and substrate, and by 
internal factors such as seed viability, moisture content, desiccation tolerance, dormancy and hormonal balance (MARCOS-FILHO, 2015). Gibberellin is the plant hormone that promotes seed germination, acting in the synthesis of hydrolytic enzymes that are essential to the degradation of reserves accumulated in the endosperm and embryo, releasing energy for primary root protrusion and elongation (TAIZ; ZEIGER, 2013).

Scientific studies have been conducted to evaluate the beneficial aspects of the association of plant growth-promoting rhizobacteria (PGPR) with germination of agricultural seeds and plant growth, such as bacteria of the genus Azospirillum (HUNGRIA, 2011; BRACCINI et al., 2012; DARTORA et al., 2013; COTRIM et al., 2016; GALEANO et al., 2019). Rhizobacteria colonize the roots or adjacent layer of the root system called plant rhizosphere, promoting benefits to plant growth and/or development (KLOEPPER; SCHROTH, 1978).

Microorganisms act in plant growth through nitrogen fixation mechanisms and in the production of plant hormones such as gibberellin (CASSÁN et al., 2003), promoting an increase in seed germination and seedling vigor (COTRIM et al., 2016). In addition, they improve the quality of roots with effects on the increase in the number of root hairs and lateral roots (ARORA et al., 2013), besides inhibiting the growth of harmful fungi (ARAÚJO et al., 2010). Indeed, the use of these bacteria stimulates plant growth and reduces the time of the production cycle in a nursery, with seedlings of higher quality and greater potential for survival in the field to establish the plantations.

However, there are few studies using rhizobacteria in seed germination and initial growth of native forest species, and there are promising reports for Peltophorum dubium (Spreng.) Taub. and Leucaena leucocephala (Lam.) de Wit. (RAMPIM et al., 2014). Inoculation of these microorganisms can be a low-cost and easy-to-use technology for producing seedlings of these species, aiming at a good development in the field. Based on this, the present study aimed to evaluate the potential of Azospirillum brasilense inoculation in the germination of seeds and initial growth of seedlings of native forest species.

\section{MATERIAL AND METHODS}

The experiment was conducted at the Department of Forest Sciences of the Universidade Federal do Paraná, located in Curitiba, Paraná State, Brazil. The climate of the region is Cfb (humid subtropical with mild summer) according to Köppen's classification (ALVARES et al., 2013).

Two experiments were carried out: (I) germination of seeds and (II) initial growth of seedlings, with four native forest species, Cassia leptophylla Vogel. (Fabaceae), Lafoensia pacari Saint-Hilaire (Lythraceae), Mimosa flocculosa Burkart (Fabaceae) and Schinus terebinthifolius Raddi. (Anacardiaceae). For the four species, in both experiments, two treatments were used: inoculation of seeds with concentrated solution of A. brasilense, and no inoculation of seeds (control).

The moisture content of the seeds of each species was previously determined with two replicates of 100 seeds subjected to the oven method at $105 \pm 3{ }^{\circ} \mathrm{C}$ for $24 \mathrm{~h}$, whose results were expressed as a percentage (BRASIL, 2009). The solution of A. brasilense was obtained commercially (AzoTotal ${ }^{\circledR}$ ) at a concentration of 1.0 g. $\mathrm{cm}^{-3}$ of solution with the presence of the bacterium (strains AbV5 and AbV6).

In the germination experiment, for each species, there were four replicates of 50 seeds per treatment, which were previously disinfested in sodium hypochlorite solution at $2.5 \%$ ( $\mathrm{NaClO}$ ) for 5 min (BRASIL, 2009) and rinsed three times with distilled water. The physical dormancy of C. leptophylla and M. flocculosa seeds (seed coat impermeability to water) was overcome by a cut in the opposite region to the micropyle before asepsis.

The seed inoculation treatment was performed by total immersion in a commercial solution of $A$. brasilense for $1 \mathrm{~min}$, while seeds of the control treatment were not inoculated. Sowing was done immediately after inoculation, using three sheets of paper towels (Germitest ${ }^{\circledR}$ type) moistened with distilled water using a volume equivalent to twice and a half the weight of the dry paper. They were organized in the form of rolls, placed in transparent plastic bags and kept in a germination chamber (BOD type) regulated at $25^{\circ} \mathrm{C}$ with a photoperiod of $12 \mathrm{~h}$ (BRASIL, 2013), during 14 days (C. leptophylla and M. flocculosa) and 21 days (L. pacari and $S$. terebinthifolius), respectively.

In the first experiment, the following parameters were evaluated: percentage of normal seedlings (all structures intact or with minor defects) and abnormal seedlings formed, at the end of the time stipulated for germination, according to recommendations of Brasil (2009); germination speed index (GSI) and mean germination time (MGT); length (measurement with millimeter ruler) and dry weight (drying in an oven at $65^{\circ} \mathrm{C}$ for $72 \mathrm{~h}$ ) of the root system, shoots and total of normal seedlings, whose results were expressed in centimeters per seedling (cm.seedling $\left.{ }^{-1}\right)$ and milligrams per seedling ( $\left.\mathrm{mg}_{\text {.seedling }}{ }^{-1}\right)$, respectively; in addition to the ratios of root length/shoot length and root dry weight/shoot dry weight. 
In the experiment of initial growth of seedlings, for each species, the seeds were previously inoculated, as specified in the first experiment, and sown in tubes with 6 internal striations and volume of $55 \mathrm{~cm}^{3}$. The containers were filled with commercial substrate based on pine bark and kept in a protected nursery with $50 \%$ solar radiation and daily irrigation (micro-sprinkler) for five months. In this experiment, four repetitions of 20 seedlings per treatment were used for each species.

The following parameters were evaluated in the second experiment: seedling height in centimeters (measurement with a ruler graduated in millimeters); collar diameter in millimeters (digital caliper $0.01 \mathrm{~cm}$ ); root dry weight, shoot dry weight and total dry weight, whose results were expressed in milligrams per seedling (mg.seedling $\left.{ }^{-1}\right)$.

The experimental design used was completely randomized for each experiment, with four replicates per treatment (without and with inoculation of A. brasilense). The data were subjected to analysis by Student's t-test for independent samples at 5\% probability level. Then, simple Pearson's correlation $\left(\mathrm{r}_{\mathrm{p}}\right)$ was performed at $5 \%$ probability level by t-test to evaluate the effect of rhizobacteria on each variable. The statistical program used was Sisvar $^{\circledR}$ (version 5.4).

\section{RESULTS}

\section{Experiment I: germination of seeds}

Inoculation of seeds with $A$. brasilense did not significantly influence the germination of seeds and vigor of seedlings of C. leptophylla, L. pacari, M. flocculosa and S. terebinthifolius based on the physiological aspects evaluated. The moisture contents of the seeds of the forest species used were $14.4 \%$ for C. leptophylla, $12.9 \%$ for L. pacari, $7.6 \%$ for M. flocculosa and $11.4 \%$ for S. terebinthifolius.

The germination of $C$. leptophylla seeds with A. brasilense inoculation decreased from $80 \%$ to $65 \%$, while the percentage of abnormal seedlings increased from $8 \%$ to $16 \%$, indicating possible harmful effect of the rhizobacteria for this species (Figure 1). The germination speed index and mean germination time (GSI and MGT) of the studied species were not significantly affected by the inoculation of A. brasilense.

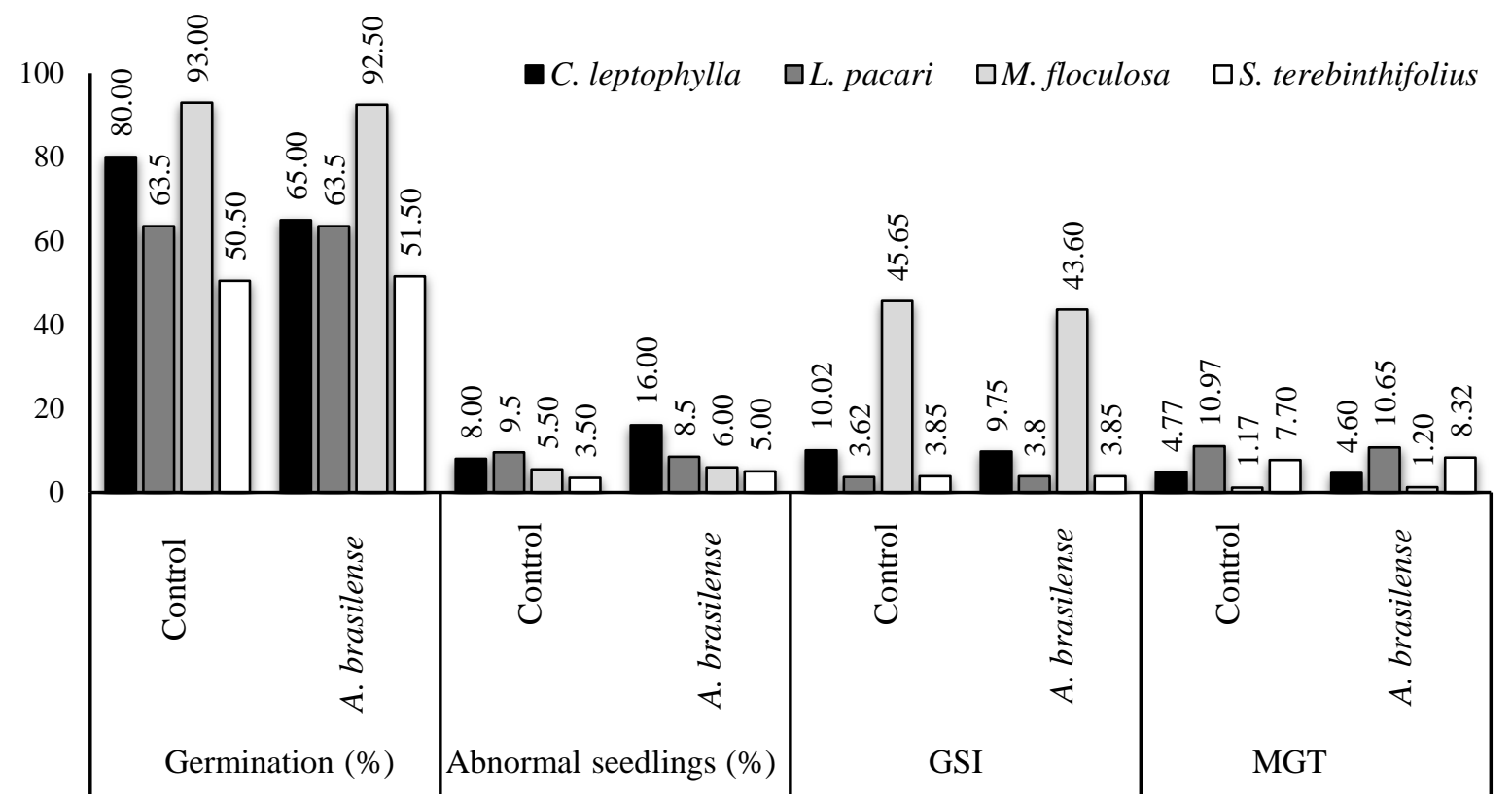

Figure 1: Germination, abnormal seedlings, germination speed index (GSI) and mean germination time (MGT) of C. leptophylla, L. pacari, M. flocculosa and S. terebinthifolius as a function of seed germination without and with $A$. brasilense inoculation.

Figura 1: Germinação, plântulas anormais, índice de velocidade de germinação (GSI) e tempo médio de germinação (MGT) de C. leptophylla, L. pacari, M. flocculosa e S. terebinthifolius submetidas a germinação de sementes sem e com inoculação de $A$. brasilense.

The inoculation of $A$. brasilense did not interfere in the root growth of the studied species during germination, not significantly affecting the root, shoot and total length and dry weight of their seedlings, as well as the ratios of root length/shoot length and root dry weight/shoot dry weight (Figures 2 and 3). Although seed inoculation with $A$. brasilense did not improve the length and dry weight of the root system, secondary roots 
tended to increase for M. flocculosa, L. pacari and S. terebinthifolius, while for C. leptophylla there was no increase in the growth of secondary roots.

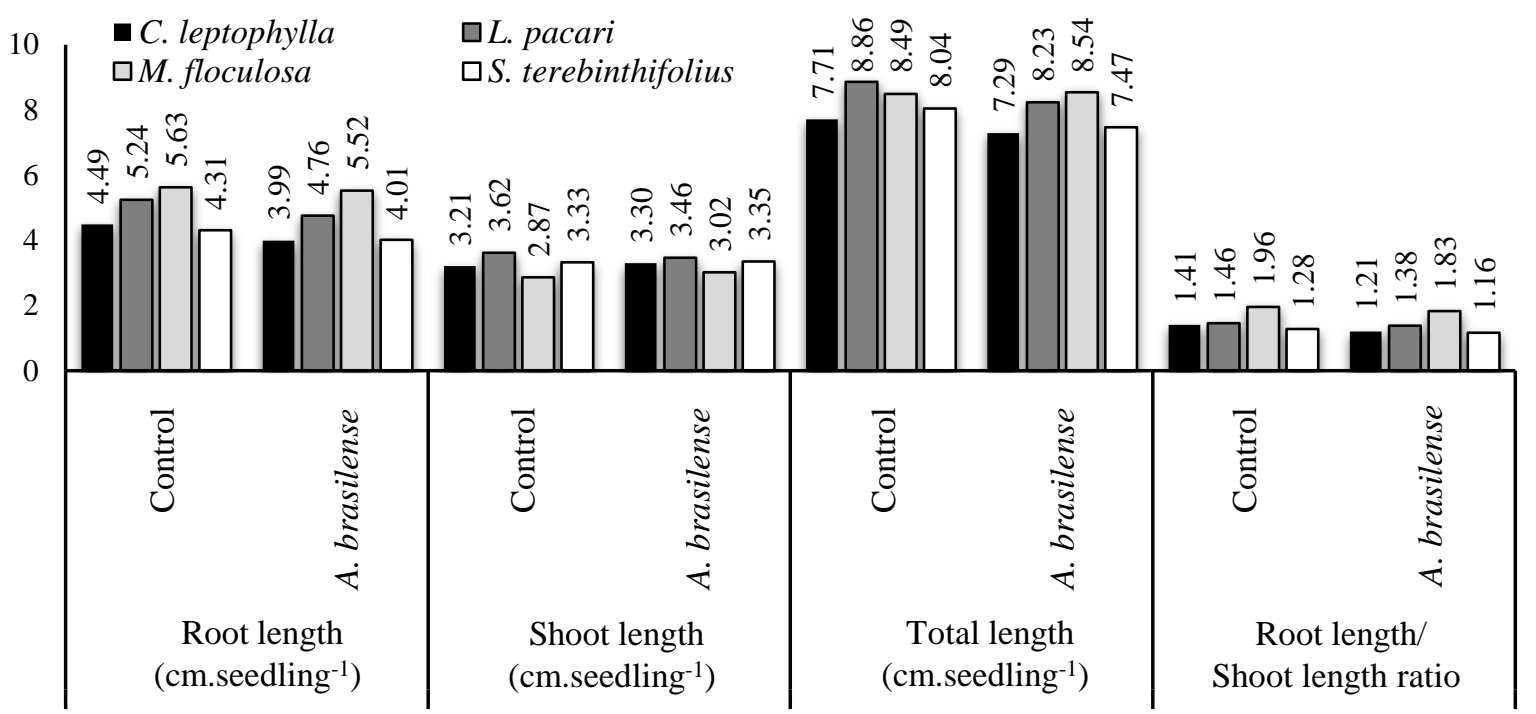

Figure 2: Root length, shoot length, total length, and root length/shoot length ratio of C. leptophylla, L. pacari, M. flocculosa and S. terebinthifolius seedlings as a function of seed germination without and with $A$. brasilense inoculation.

Figura 2: Comprimento da raiz, parte aérea, total, e relação raiz/parte aérea de plântulas de C. leptophylla, L. pacari, M. flocculosa e S. terebinthifolius submetidas a germinação de sementes sem e com inoculação de A. brasilense.

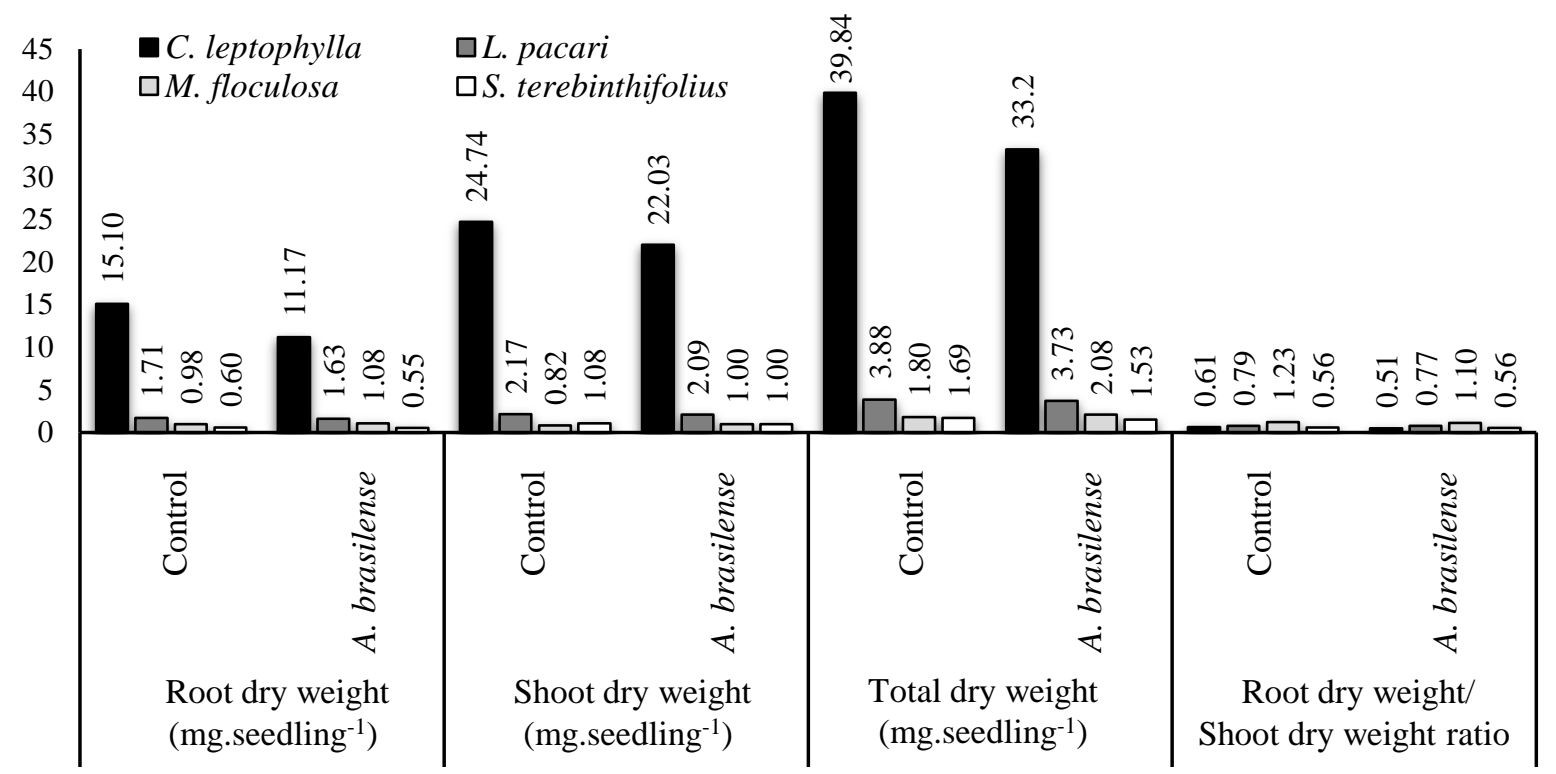

Figure 3: Root dry weight, shoot dry weight, total dry weight and root dry weight/shoot dry weight ratio of $C$. leptophylla, L. pacari, M. flocculosa and S. terebinthifolius seedlings as a function of seed germination without and with $A$. brasilense inoculation.

Figura 3: Massa seca da raiz, parte aérea, total e relação raiz/parte aérea de plântulas de C. leptophylla, L. pacari, M. flocculosa e $S$. terebinthifolius submetidas a germinação de sementes sem e com inoculação de $A$. brasilense. 


\section{Experiment II: initial growth of seedlings}

The initial growth of L. pacari, M. flocculosa and S. terebinthifolius seedlings in nursery was not affected by $A$. brasilense inoculation, and for C. leptophylla, the seedlings of both treatments did not survive until the end of the experiment, so they were disregarded from the analyses. For the effects of inoculation, it was observed that the height and diameter of the seedlings (Figure 4) and their shoot, root, and total dry weight (Figure 5) were not affected. However, it was possible to observe the growth of secondary roots with the use of rhizobacteria compared to control (Figure 6).

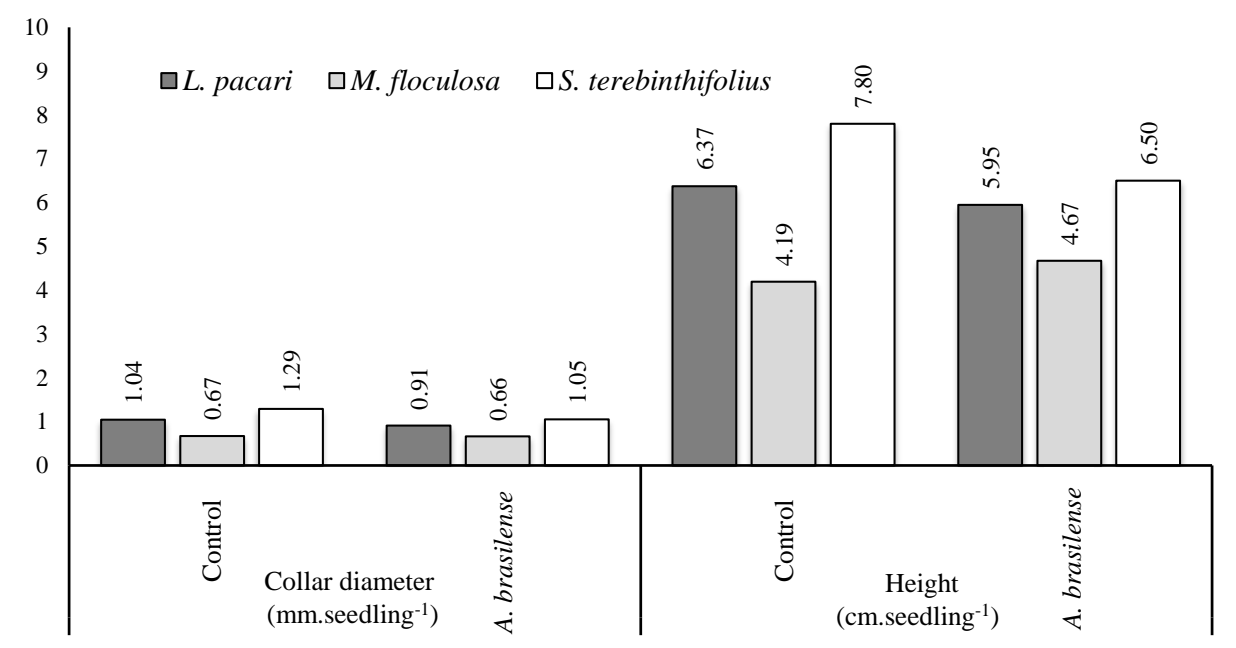

Figure 4: Collar diameter and height of L. pacari, M. flocculosa and S. terebinthifolius seedlings as a function of seed germination without and with $A$. brasilense inoculation.

Figura 4: Diâmetro do colo e altura das mudas de L. pacari, M. flocculosa e S. terebinthifolius submetidas a germinação de sementes sem e com inoculação de A. brasilense.

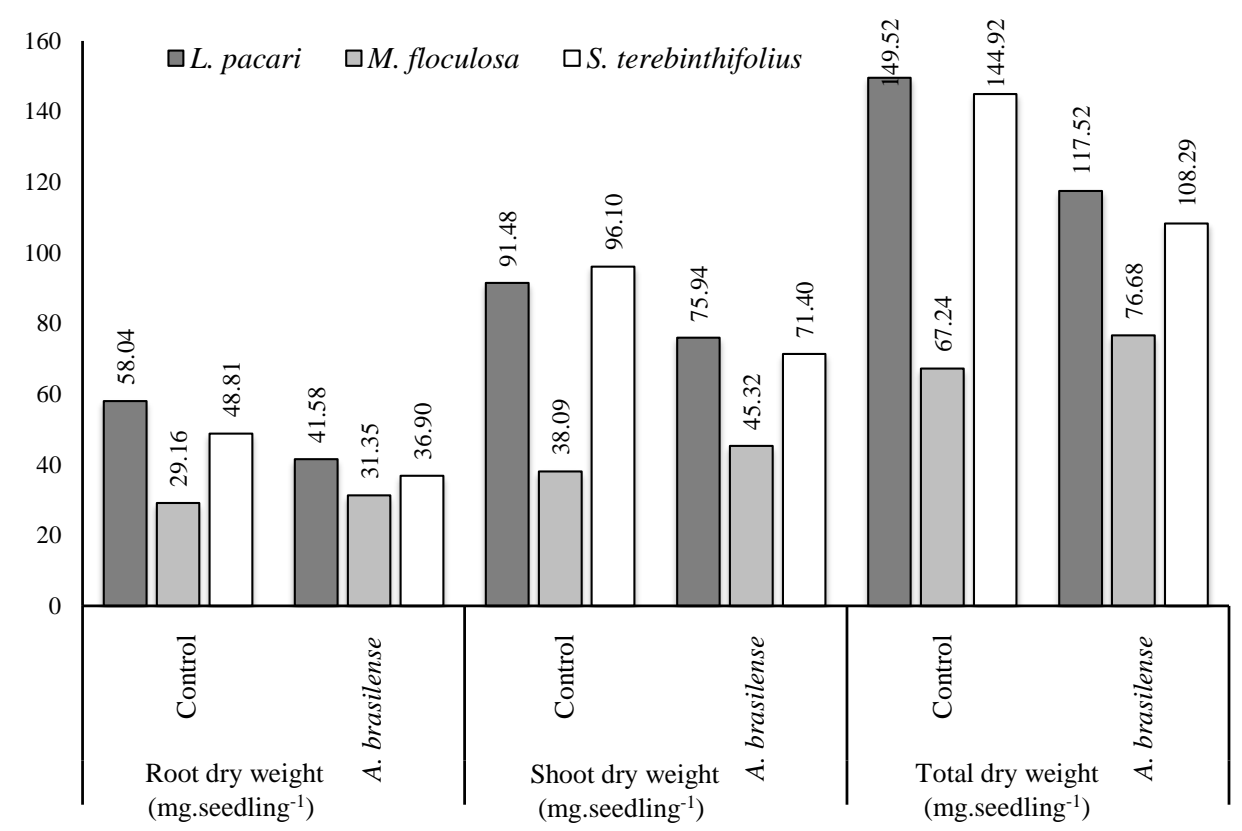

Figure 5: Root dry weight, shoot dry weight and total dry weight of L. pacari, M. flocculosa and S. terebinthifolius seedlings as a function of seed germination without and with A. brasilense inoculation.

Figura 5: Massa seca da raiz, parte aérea e total de plântulas de L. pacari, M. flocculosa e S. terebinthifolius submetidas a germinação de sementes sem e com inoculação de A. brasilense. 


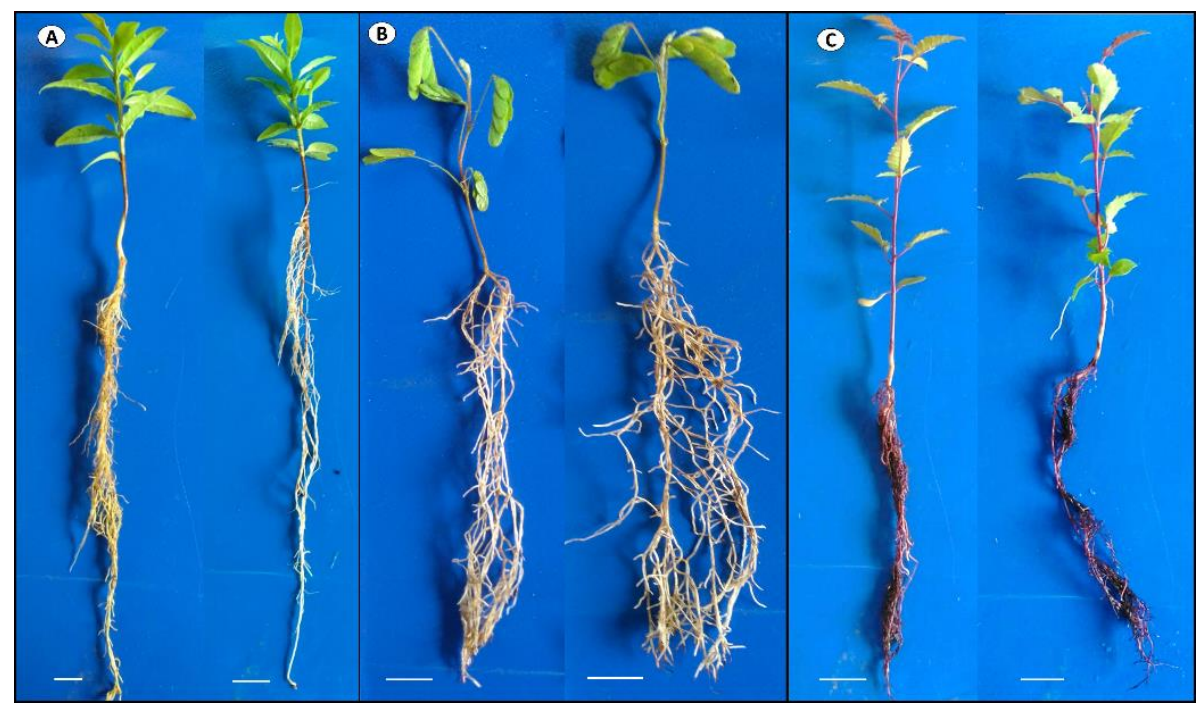

Figure 6: Seedlings of L. pacari (A), M. flocculosa (B) and S. terebinthifolius (C) as a function of seed germination without (seedling on the left) and with (seedling on the right) A. brasilense inoculation (scale: $1 \mathrm{~cm}$ ).

Figura 6: Mudas de L. pacari (A), M. flocculosa (B) e S. terebinthifolius (C) submetidas a germinação de sementes sem (plântula da esquerda) e com (plântula da direita) inoculação de A. brasilense (escala: 1 $\mathrm{cm})$.

Although there were no significant differences between treatments for each species in the two experiments, there is a correlation $\left(\mathrm{r}_{\mathrm{p}}\right)$ between inoculation of A. brasilense and reduction in germination ($\left.0.807^{* *}\right)$, germination speed (GSI: $-0.998^{* *}$ and MGT: $\left.0.983^{* * *}\right)$, root length $\left(-0.854^{* *}\right)$, shoot length $\left(-0.704^{* *}\right)$ and root length/shoot length ratio $\left(-0.889^{* * *}\right)$ during seed germination, as well as for the variables of seedling dry weight (root: $-0.985^{* *}$, shoot: $-0.987^{* *}$, total: $-0.986^{* *}$, and root/shoot ratio: $-0.923^{* *}$ ). Conversely, collar diameter $\left(-0.911^{* *}\right)$ decreased with the addition of $A$. brasilense in the initial growth of seedlings (Table 1). Therefore, the use of $A$. brasilense does not benefit the germination of seeds and growth of seedlings of these species.

Table 1: Simple Pearson's correlation $\left(r_{p}\right)$ for A. brasilense inoculation in each physiological parameter evaluated in seed germination and initial seedlings growth.

Tabela 1: Correlação simples de Pearson $\left(\mathrm{r}_{\mathrm{p}}\right)$ para inoculação de A. brasilense em cada parâmetro fisiológico avaliado na germinação de sementes e crescimento inicial de mudas.

\begin{tabular}{cc}
\hline Variable & Correlation coefficient $\left(\mathrm{r}_{\mathrm{p}}\right)$ \\
\hline Experiment I: germination of seeds & \\
Germination & $-0.807^{* *}$ \\
Abnormal seedlings & $0.293^{\mathrm{ns}}$ \\
Germination speed index (GSI) & $-0.998^{* *}$ \\
Mean germination time (MGT) & $0.983^{* *}$ \\
Root length & $-0.854^{* *}$ \\
Shoot length & $-0.704^{* *}$ \\
Total length & $-0.619^{\mathrm{ns}}$ \\
Root length/shoot length ratio & $-0.889^{* *}$ \\
Root dry weight & $-0.985^{* *}$ \\
Shoot dry weight & $-0.987^{* *}$ \\
Total dry weight & $-0.986^{* *}$ \\
Root dry weight/shoot dry weight ratio & $-0.923^{* *}$ \\
Collar diameter & $-0.912^{* *}$ \\
Seedling height & $-0.476^{\mathrm{ns}}$ \\
Root dry weight & $-0.312^{\mathrm{ns}}$ \\
Shoot dry weight & $-0.566^{\mathrm{ns}}$ \\
Total dry weight & $-0.507^{\mathrm{ns}}$ \\
\hline
\end{tabular}

${ }^{\mathrm{ns}}$ not significant and ${ }^{* *}$ significant at $5 \%$ probability level.

${ }^{\text {ns }}$ não significativo e ${ }^{* *}$ significativo ao nível de $5 \%$ de probabilidade. 


\section{DISCUSSION}

The germination of C. leptophylla, L. pacari, M. flocculosa and S. terebinthifolius seeds was not positively affected by the inoculation of $A$. brasilense, demonstrating that this specific bacterium does not favor the germination process and growth of seedlings of the studied species. The use of rhizobacteria in cotton showed excellent results in seed germination and shoot growth (LIMA et al., 2018), while in wheat there was no significant difference (GALEANO et al., 2019). In forest species, Rampim et al. (2014) observed that inoculation in seeds of P. dubium and L. leucocephala with strains of A. brasilense and Bradyrhizobium elkanii significantly increased seedling emergence, allowing a better adaptation of the stand in the production systems employed. Therefore, the results among different species need to be studied individually without generalizations.

The impermeability of the seed coat to the entry of solutes and the time of exposure of the bacterium to the seeds may be among the causes that influenced the obtaining of unsatisfactory results, since the bacterium was inoculated by immersion of seeds. According to Moreira et al. (2014), the association of seeds with microorganisms can cause a different development of the embryo induced by growth phytohormones produced by rhizobacteria, which penetrate the seed coat along with water, accelerating the growth of roots and increasing their absorption capacity, without acting directly in the germination process.

Plant hormones produced by rhizobacteria, such as auxins, gibberellins and cytokinins, act in cell division and root development, resulting in overproduction of lateral roots and root hairs, with consequent increase in the absorption of minerals and water (ARORA et al., 2013). In addition, gibberellin and cytokinin also act in seed germination and seedling shoot development (ALMEIDA; RODRIGUES, 2016). However, for the studied species, the use of $A$. brasilense was not effective for seed germination and caused reduction in the vigor of the seedlings formed, evidenced by the correlations between the inoculation of $A$. brasilense and the physiological parameters evaluated (Table 1).

The initial growth of L. pacari, M. flocculosa and S. terebinthifolius seedlings in nursery was not favored by A. brasilense inoculation; for these species, only collar diameter showed negative correlation ($0.911^{* * *}$ ) with inoculation of A. brasilense in the nursery stage (Table 1). According to Santos et al. (2018), inoculation with A. brasilense is not favorable to the development of Pinus taeda L. in nurseries, although several studies prove the benefits of this bacterial species for agricultural crops. For P. dubium, inoculation with the $A$. brasilense strain increased shoot dry weight, shoot length and root length, and reduced collar diameter, as in the present study; while for L. leucocephala, it increased shoot dry weight and root system length (RAMPIM et al., 2014). These results are possibly related to the higher production of auxins promoted by the rhizobacteria.

The use of the bacterium promoted increments in root dry weight and protein content in agricultural species, acting on the photosynthetic mechanism and promoting improvements in nitrogen assimilation (GALEANO et al., 2019). These results suggest that the rhizobacterium promoted a higher concentration of auxin when compared to gibberellin, and auxin is the plant hormone responsible for increasing the number of lateral roots and proliferation of fine roots (CASSÁN et al., 2003).

These results show that the action of plant growth-promoting rhizobacteria (PGPR) may vary from species to species, and possibly in the post-germination period, acting in the colonization of the root system (KLOEPPER; SCHROTH, 1978). Growth promotion by microorganisms depends on a set of factors, such as seed vigor, concentration, and age of the inoculum, which even under favorable physiological and edaphic conditions can promote little or no beneficial effect (HARMAN, 2000).

According to Santos et al. (2018), the negative effect of rhizobacteria on seed germination and seedling growth may be related to the interference of environmental factors in the effects of inoculation, and that each species has unique patterns of adaptation and response to the conditions of the substrate and the site of production. In addition, genetic factors of bacteria and plant species may play an important role in the results of inoculation practices.

Therefore, it is necessary to conduct studies focused on seeds whose coats have greater permeability and different periods of exposure of the seeds to the solution of A. brasilense, as well as investigating the influence of environmental factors on the inoculation of rhizobacteria. In addition, special focus should be given to the use of this rhizobacterium after the beginning of the germination process, when the root system is growing and more receptive to the contact with the bacterium.

\section{CONCLUSION}

- Inoculation of Azospirillum brasilense in seeds of Cassia leptophylla, Lafoensia pacari, Mimosa flocculosa and Schinus terebinthifolius did not promote beneficial or promising results for seed germination and initial growth of seedlings, so its use to produce seedlings of these species is not recommended. 


\section{ACKNOWLEDGMENTS}

To the Conselho Nacional de Desenvolvimento Científico e Tecnológico (CNPq) and the Coordenação de Aperfeiçoamento de Pessoal de Nível Superior (CAPES), for granting scholarships to the authors involved.

\section{REFERENCES}

ALMEIDA, G. M.; RODRIGUES, J. G. L. Development of plants by interference auxins, cytokinins, gibberellins and ethylene. Applied Research \& Agrotechnology, Guarapuava, v. 9, n. 3, p. 111-117, 2016.

Alvares, C. A., STAPE, J. L.; SENTElHAS, P. C.; GONÇALVES, J. L. M.; SPAROVEK, G. Köppen's climate classification map for Brazil. Meteorologische Zeitschrift, Stuttgart, v. 22, n. 6, p. 711-728, 2013.

ARAÚJO, A. E. S.; ROSSETO, C. A. V.; BALDANI, V. L. D.; BALDANI, J. I. Rice seed germination and vigour as affected by the inoculation with diazotrophic bacteria. Ciência e Agrotecnologia, Lavras, v. 34, n. 4, p. 932-939, 2010.

ARORA, N. K.; TEWARI, S.; SINGH, R. Multifaceted plant-associated microbes and their mechanisms diminish the concept of direct and indirect PGPRs. In: ARORA, N. K. (ed.) Plant microbe symbiosis: fundamentals and advances. Springer, cap. 16, 2013. p. 411-449.

BRACCINI, A. L.; DAN, L. G. M.; PICCININ, G. G.; ALBRECHT, L. P.; BARBOSA, M. C.; ORTIZ, A. H. T. Seed inoculation with Azospirillum brasilense associated with the use of bioregulators in maize. Revista Caatinga, Mossoró, v. 25, n. 2, p. 58-64, 2012.

BRASIL. Regras para análise de sementes. Ministério da Agricultura, Pecuária e Abastecimento. Secretaria de Defesa Agropecuária. Brasília: MAPA, 2009. 399 p.

BRASIL. Instruções para Análises de Sementes de Espécies Florestais. Ministério da Agricultura, Pecuária e Abastecimento. Secretaria de defesa Agropecuária. Brasília: MAPA, 2013. 97 p.

CASSÁN, F. D.; PICCOLI, P.; BOTTINI, R. Promoción del crecimiento vegetal por Azospirillum sp. através de la producción de giberelinas. ¿Un modelo alternativo para incrementar la producción agrícola? In: ALBANESI et al. (eds) Microbiología Agrícola: Un aporte de la investigación argentina. Santiago del Estero, Argentina. 2003. $143-158 \mathrm{p}$.

CHAZDON, R. L.; BRANCALION, P. H. S.; LAESTADIUS, L.; BENNETT-CURRY, A.; BUCKINGHAM, K.; KUMAR, C.; MOLL-ROCEK, J.; VIEIRA, I. C. G.; WILSON, S. J. When is a forest a forest? Forest concepts and definitions in the era of forest and landscape restoration. Ambio, Stockholm, v. 45, p. 538-550, 2016.

COTRIM, M. F.; ALVAREZ, R. C. F.; SERON, A. C. C. Physiological quality of wheat seeds in response to application of Azospirillum brasilense and humic acid. Brazilian Journal of Biosystems Engineering, Tupã, v. 10, n. 4, p. 349-357, 2016.

DARTORA, J.; MARINI, D.; GUIMARÃES, V. F.; PAULETTI, D. R.; SANDER, G. Seed germination and seedling early growth of corn and wheat inoculated with strains of Azospirillum brasilense and Herbaspirillum seropedicae. Global Science and Technology, Rio Verde, v. 6, n. 3, p. 190-201, 2013.

GAlEANO, R. M. S.; CAMPELO, A. P. S.; MACKERT, A.; BRASIL, M. S. Initial development and quantification of corn proteins inoculated with new strains of Azospirillum brasilense. Revista Agricultura Neotropical, Cassilândia, v. 6, n. 2, p. 95-99, 2019.

HARMAN, G. E. Myth and dogmas of biocontrol changes in perceptions derived from research on Trichoderma harzianum T-22. Plant Disease, Saint-Paul, v. 84, n. 4, p. 377-393, 2000.

HUNGRIA, M. Inoculação com Azospirillum brasilense: inovação em rendimento a baixo custo. Embrapa Soja, Londrina, Brasil, 2011. 36 p.

KLOEPPER, J.; SCHROTH, M. Plant growth-promoting rhizobacteria in radish. In: 4th International conference of plant pathogenic bacteria. Gilbert-Clarey, Tours, France. 1978, p. 879-882.

LIMA, S. F.; SIMON, C. A.; LEITEM R. C.; NOGUEIRA, K. B.; ALVAREZ, R. C. F. Humic acid and Azospirillum brasiliense applied to cotton seeds. Brazilian Journal of Agriculture, Piracicaba, v. 93, n. 1, p. $01-11,2018$. 
MARCOS-FILHO, J. Fisiologia de sementes de plantas cultivadas. 2. ed. Londrina, PR: ABRATES, 2015. $660 \mathrm{p}$.

MESQUiTA, C. B.; HOLVORCEM, C. G. D.; LYRIO, C. H.; MENEZES, P. D. Cooplantar: a Brazilian initiative to integrate forest restoration with job and income generation in rural areas. Ecological Restoration, Wisconsin, v. 28, p. 199-207, 2010.

MOREIRA, C. D. A; PEREIRA, D. H.; COIMBRA, R. A.; MOREIRA, I. D. A. Germination of grasses due to inoculation diazotrophic bacteria. Scientific Electronic Archives, Rondonópolis, v. 6, n.1, p. 90-96, 2014.

RAMPIM, L.; KLEIN, J.; TSUTSUMI, C. Y.; MARCHIOTTI, B. G.; GUIMARÃES, V. F. Initial development of plants of Peltophorum dubium and Leucaena leucocephala inoculated with diazotrophic bacteria. Floresta, Curitiba, v. 44, n. 4, p. 597-606, 2014.

RODRIGUES, R. R.; GANDOLFI, S.; NAVE, A. G.; ARONSON, J.; BARRETO, T. E.; VIDAL, C. Y.; BRANCALION, P. H. S. Large-scale ecological restoration of high-diversity tropical forests in SE Brazil. Forest Ecology and Management, Flagstaff, v. 261, n. 10, p. 1605-1613, 2011.

SANTOS, R. F.; CRUZ, S. P.; BOTELHO, G. R.; FLORES, A. V. Inoculation of Pinus taeda seedlings with plant growth-promoting rhizobacteria. Floresta e Ambiente, Seropédica, v. 25, n. 1, p. e20160056, 2018.

SILVA, A. P. M.; SCHWEIZER, D.; MARQUES, H. R.; TEIXEIRA, A. M. C.; SANTOS, T. V. M. N.; SAMBUICHI, R. H. R.; BADARI, C. G.; GAUDARE, U.; BRACALION, P. H. S. Can current tree seedling production and infrastructure meet an increasing forest restoration demand in Brazil? Restoration Ecology, Malden, v. 1, p. 1-7, 2016.

SUDING, K.; HIGGS, E.; PALMER, M.; CALLICOTT, J. B.; ANDERSON, C. B.; BAKERM, M.; GUTRICH, J. J.; HONDULA, K. L.; LAFEVOR, M. C.; LARSON, B. M. H.; RANDALL, A.; RUHL, J. B.; SCHWARTZ, K. Z. S. Committing to ecological restoration. Science, New York, v. 348, p. 638-640, 2015.

TAIZ, L.; ZEIGER, E. Fisiologia vegetal. 5. ed. Porto Alegre: Artmed, 2013. 918 p. 